\title{
Interventions For Harmful and Risky Alcohol Consumption in Family Medicine
}

\section{/ Pristup osobama s rizičnim i štetnim konzumiranjem alkohola u ordinaciji obiteljske medicine}

\author{
Kristina Sambol, Tatjana Cikač
}

Community Health Care Centre, Varaždin, Croatia, 'General Practice Outpatient Department Tatjana Cikač, Varaždin, Croatia

/ Dom zdravlja Varaždinske županije, Varaždin, Hrvatska, 'Specijalistička ordinacija obiteljske medicine Tatjana Cikač, Varaždin, Hrvatska

Alcoholism is a chronic and progressive disease that includes problems controlling alcohol intake, being preoccupied with alcohol, continuing to use alcohol even when it causes problems and physical dependence. It is possible to have a problem with alcohol even when it has not progressed to the point of alcoholism. A drinking problem means that a person drinks too much at times, causing repeated problems in their family, although they are not completely dependent on alcohol. Identifying and managing alcoholism before it has interfered with the patient's career and family may increase the possibility of long-term recovery. The purpose of this article is to present how to manage alcohol problems in family medicine.

/ Alkoholizam je kronična i progresivna bolest koja uključuje sljedeće simptome: žudnja, gubitak kontrole, fizička ovisnost, tolerancija, nastavak pijenja unatoč spoznaji o štetnosti alkohola te zanemarivanje radnih i drugih obveza. Kod osoba koje nisu razvile ovisnost o alkoholu već mogu kontrolirati svoje pijenje te prilikom prestanka ne osjećaju posljedice ustezanja govorimo o zlouporabi ili štetnom uzimanju alkohola. To su osobe koje konzumiraju veću količinu alkohola dulje vrijeme pri čemu nastaju obiteljski i zdravstveni problemi, ali i oni koji negativno utječu na širu zajednicu. Ovim radom željeli smo prikazati kako u ordinaciji liječnika obiteljske medicine pristupiti pacijentu koji ima probleme s prekomjernom konzumacijom alkohola.

\author{
ADDRESS FOR CORRESPONDENCE / \\ ADRESA ZA DOPISIVANJE: \\ Kristina Sambol, MD \\ Dom zdravlja Varaždinske županije \\ Kolodvorska 20 \\ 42000 Varaždin \\ Phone: +385-98-9188034/e-mail: \\ kristina.sambol@gmail.com
}

\section{KEY WORDS / KLJUČNE RIJEČI:}

Alcohol / Alcohol

Dependence / Ovisnost

Family Medicine / Obiteljska medicina

Treatment / Liječenje 


\section{INTRODUCTION}

Alcoholism is a disorder which leads to damaging all organs and biopsychosocial characteristics due to excessive and long consumption of alcoholic beverages. According to the tenth revision of the International statistical classification of diseases and related health problems (ICD-10), alcoholism is placed under "Mental disorder and behaviour disorder due to consumption of psychoactive substances" chapter (1). Alcohol misuse means drinking more than recommended limits of alcohol consumption. Alcohol is measured in units. Standard drink have about 14 grams of pure alcohol. A small glass of vine (125 mL), glass of bear $(350 \mathrm{~mL})$ or one spirit $(40 \mathrm{~mL})$ contains about one unit of alcohol. Men should not drink regularly more than 3-4 units of alcohol a day and woman more than 2-3 units a day. Regularly means drinking every day or most days of the week. The assumption is that, currently, there is at least 30 million alcoholics in the world and every year around 3.3 million people die because of alcoholism (2). Almost $25 \%$ of death cases between the age of 20 and 39 is associated to excessive alcohol consumption (2). Globally individuals above 15 years of age drink on average 6.2 liter of pure alcohol per year what is 13.5 of pure alcohol per day. The highest consumption is found in developed world. A recent report indicated that in EU 1 in every 7 deaths in men and 1 in every 13 deaths in women in the group from 15 to 64 years was due to alcohol consumption (2). Over past few decades alcohol consumption in some areas of Europe has decreased. Levels of alcohol attributable deaths are still high in Europe especially in central and eastern country group where alcohol consumption is on the increase. Even though alcoholism is considered an illness for the, so called, social drinking is an important way of life both for individuals and families. Alcoholic way of life is manifested by high drinking and drinking habit tolerance and the first family problems are not recognized as important by the surroundings. Alcoholism is first manifested on a family level. The majority of alcoholics who seek treatment are married and have, in average, two children. The number of single alcoholics is lesser and they are mostly younger people. In Croatia there are around 200 thousand alcoholics, 200 thousand people who drink too much and 700 thousand people who, either directly or indirectly, suffer because of alcoholism (3). Mental disorders and behavioral disorders caused by alcohol abuse represent, in regard to stationary hospitalization, the leading psychiatric diagnosis in the Republic of Croatia (4). According to WHO recorded alcohol per capita consumption (liters of pure alcohol) in Croatia during 2011 was 10.63 (2). This shown some decrease according to previous years. During 2010 in Croatia were 80.5 \% of alcohol consumers $(91.8 \%$ of man and $70.3 \%$ of woman) (2). There was $19.5 \%$ of abstainers in 2011 (8.2 \% of man and $29.7 \%$ of woman) (2). Average daily intake in grams of alcohol among drinkers in 2010 was 41.7 in male population and 22.8 in female. WHO project that total consumption of alcohol per capita (15+) in Croatia will decrease from 11.7 in 2015 to 10.8 in 2025 (2). As comorbidity of depressive and anxiety disorders, post-traumatic stress disorder and personality disorders is well known and often present in alcohol addicted patients, it is clear that alcohol addiction poses a major public health problem in Croatia, as well as worldwide (4).

\section{CASE REVIEW}

S.V. is a woman, age 45 , who came to the family practice office for consultation regarding her insomnia, dejection and, as she described it, depression she has been feeling for some time. During the conversation she mentions difficulties in form of lethargy during her work hours. Despite of that she has been fulfilling her work obligations. She is working as 
a sales person for lottery and other games of chance. She had problems waking up, usually between 2 and $3 \mathrm{AM}$ in the morning, and going back to sleep. She is married for 23 years and has a daughter who is 21 years old. She lives in an apartment with her husband who is a procurement manager at a private company. He is described as a supportive and understanding husband. Her daughter lives with her husband and 1 year old child in a house just outside the town. The entire family is described as pleasant and the kind you can rely on. Her father suffers from hypertension and mother from diabetes. The patient has been smoking for last 15 years, up to 10 cigarettes a day. Up until now she didn't have any serious illness and wasn't under constant therapy. Occasionally, because of the insomnia problems, she takes a $5 \mathrm{mg}$ diazepam and an analgesic drug for her headaches which she buys herself at a drugstore. For the last three months she has been feeling worse than before. She's experiencing grief and melancholy but can't find the reasons or changes that might have led her to such state. After a longer conversation she admits that the situation at home is a bit tenser. The husband might lose his job and there are also some financial problems. She also noticed that she lost interest for her usual activities. She feels insecure and lack of self-worthy. She denies thinking about death or suicide. There is no vomiting or loss of weight. She seems a bit dull and talks slowly. She also admits that she sometimes has a drink at home after work, just to relax. Mostly its rum and beer. Every day she drinks at least one beer, on the weekends it's two. Also, on the weekends, the number of hard liquor shots per day goes up to 5 and during the week it's around 2. She didn't show a great concern regarding her drinking. She did mention that maybe she should decrease the amount of alcohol she drinks during the weekends. Her husband and daughter have been telling her to slow down with the drinking and that, in their opinion, she might have a prob- lem with alcohol. Their opinion did not bother her too much, but after those conversations she did feel guilty for drinking. When asked if she ever has a drink in the morning, immediately after she wakes up, she admitted that in the last couple of months she has a rum before work just to relax. When asked if she drinks at work, she started crying. She said that 2 or 3 times a week, during work, she goes and buys vodka which she then drinks at work. She then takes one small bottle home. After the anamnesis was done we have take AUDIT-C questioner to see severity of alcohol problem. Her score was 9 which indicated serious alcohol problem. She was diagnosed with alcoholism and offered treatment. She was also sent to laboratory tests for possible liver dysfunction. For this estimation determining the value of enzyme GGT is used. Apart from that, AST and ALT ratio is also taken into consideration. Their ratio should be, at least, 2:1 in favour of AST. The patient had 425 GGT, 141 AST and 73 ALT. She was introduced to the diagnosis and the process of treatment. While talking to her we showed great understanding of her problem. She accepted the recommendation for treatment, but refused hospitalization. Her opinion was that the problem can be solved at home with the help of her husband and daughter. She stated that her problem was not that big so she does not have to stay in a hospital. Our help was accepted in form of support, we agreed she would come to the clinic every two weeks so we could track her progress. She liked the idea to include her husband into therapy as time went by. She was also advised to join the alcoholics group which was formed on the county level and has meetings two times a week. She still wasn't ready for that. Since she refused to be hospitalized, we explained that after 72 hours without alcohol the signs of abstinence crisis will appear. It was agreed that she will phone the clinic every day in that period for assessment of progress. She was warned to contact her doctor if she becomes febrile, starts vomit- 
ing, has chest pain or dyspnea, hallucinations. Escitaloparm in $10 \mathrm{mg}$ dose and diazepam in 5 mg was also included in her therapy.

\section{DISCUSSION}

Alcoholism is an addictive illness, which also include other forms of addiction, e.g. drug addiction, tobacco addiction, etc. An alcoholic will continue drinking despite serious family and health issues and problems with the law. Alcoholism is a chronic illness, and its risk factors include genetic predispositions as well as lifestyle habits. Society pays a great deal for non-health related, so-called social, consequences of alcoholism in the form of social disorders, degraded labor ability, traffic accidents, fires, welfare, etc. (5). Alcohol addiction includes the following six symptoms: craving (great desire for alcohol), loss of control (inability to stop drinking once started), physical activity (when the drinking is stopped, intense sweating, tremors and nausea appear), tolerance (more alcohol needs to be consumed to reach the desired state), neglecting family and other responsibilities and continuing drinking despite knowing about its adverse effects (6). Studies over the last couple of years were focused on finding a genetic basis for alcoholism, but it was not established that alcoholism is a congenital illness. The environment in which a person lives and works, stress and accessibility of alcoholic drinks also contribute to alcoholism. Alcoholism is curable, meaning that the addict can establish permanent abstinence. An alcohol addict can never control his drinking again even though abstinence has been successfully achieved. If they do start drinking again, relapse can occur. Treatment is performed with social support and medical treatment, which includes individual and group therapy, family therapy, usage of medicaments and joining an Alcoholic Anonymous (AA) group (7). The program includes a clinical treatment of up to one month, after which the rehabilitation continues in an AA group. The AA group is a community based on the principle of self-help and mutual assistance. The group works as a non-profit citizens' association dedicated to helping people who continue to receive treatment for alcoholism after hospital treatment, people with problems caused by alcoholism who were not on hospital treatment and family members (8). Today there are about 800 AA groups in Croatia, which are significant for the resocialization and rehabilitation of patients (9). During group counseling, the group provides an opportunity for each member to actively participate in their own treatment process. By exchanging personal stories and experiences with others who were in the same or similar situation, they get acquainted with themselves and their behavior as well as the fact that they are not the only ones who have the problem of addiction (8). The purpose of counseling is to encourage the acceptance process and create conditions for positive changes in the absentee's life (8). During treatment, sedatives are introduced into therapy, preventing the development of reluctance symptoms (tension, tremors, sweating) (10). At the beginning of treatment, usage of antidepressants is indicated, which stabilize the general psychological state of the patient. We also use disulfiram (antabuse, esperal) (1). This is an aid which helps the alcoholic to maintain his abstinence based on the fear of unwanted consequences if alcohol is consumed along with disulfiram. Simultaneous consummation of alcohol and disulfiram causes enhanced sweating, nausea, feeling of suffocation, chest pressure, palpitations, high blood pressure, headache and vomiting (1). Abstinence is the goal of the treatment but requires changes in the current way of life. By changing the way of life, the attitude towards alcohol also changes. All family members have to be included in the treatment as well, with the goal of establishing new interpersonal relations and starting a better fam- 
ily life. All alcohol-related consequences can be divided into two groups. Problems which occur immediately after consuming alcohol (acute intoxication) belong to the first group (10). Changes in the behavior of individuals in direct relation with concentration of consumed alcohol are dominant here. At lesser concentration (up to $1.5 \%$ ), improved mood, verbosity and leisure behavior are dominant. By increasing the concentration of alcohol in blood, the state of the mind changes from drowsiness to a coma. The second group of consequences includes the ones which appear with long-term excessive consummation of alcohol and are shown in table 1 (10). Damage of the gastric mucosa (gastritis), the liver with highest likelihood of complication (cirrhosis) and pancreas (acute and chronic pancreatitis) may appear. Long-term consummation of alcohol may also lead to damage to the peripheral nerves (patients complain about burning, prickling pain and ache in the calf and pain which occurs while walking) (11). Brain damage is manifested in difficulties with memory. One of the complications is alcohol epilepsy.

An alcoholic cannot be forced into treatment unless violent breakdowns or emergency states (acute intoxication) appear (1). To encourage them to seek treatment, it is important for them to stop ignoring the problem so the alcoholic starts noticing the consequences of their excessive and uncontrolled drinking. It is necessary to choose the right moment for an intervention. The best moment to start the conversation is after an alcohol-related problem (7). It is necessary to talk to them when they are sober. A member of his family should point out that the drinking causes all kinds of problems (with examples) along with the explanation of their own feelings and points of view. It has to be insisted that the behavior cannot be tolerated anymore and that all measures will be taken to save the family (1). To motivate the alcoholic, seeking help from close friends, friends from work and other family members is advised. There will always be patients who will continue drinking because they will not or cannot stop (6). With such cases, their presentation at the clinic for a completely different reason can be used to warn them again about the harms of drinking and emphasize the advantages of implementing lifestyle changes.

Alcoholism treatment begins with estimating how much alcohol does the person actually consume and the potential risks for that person and their surroundings (figure 1) (12). Depending on the level of alcohol addiction, there are different approaches to patient treatment.

To identify and provide brief advice to patients who engage in harmful drinking, we can use the Audit consumption questions (AUDIT C). The AUDIT C tool is a modified version of the Alcohol Use Disorders Identifications Test (table 2). The test consists of three questions which help identify patients who are at risk or have an

TABLE 1. Physical consequences of excessive alcohol intake

\begin{tabular}{|c|c|c|}
\hline Gastrointestinal & Neurological & Cardiovasculatory \\
\hline $\begin{array}{l}\text { - } \text { pancreatitis } \\
\text { - cirrhosis } \\
\text { - gastritis } \\
\text { - esophageal varices }\end{array}$ & $\begin{array}{l}\text { - peripheral neuropathy } \\
\text { - seizures } \\
\text { - dementia }\end{array}$ & $\begin{array}{l}\text { - hypertension } \\
\text { - } \text { atrial fibrillation }\end{array}$ \\
\hline Hematological & Malignancies & Endocrine \\
\hline $\begin{array}{l}\text { - } \text { anemia } \\
\text { - coagulopathy }\end{array}$ & $\begin{array}{l}\text { - } \text { oral } \\
\text { - hepatic } \\
\text { - laryngeal } \\
\text { - pharyngeal } \\
\text { - colorectal }\end{array}$ & $\begin{array}{l}\text { - malnutrition } \\
\text { - electrolyte disturbances }\end{array}$ \\
\hline
\end{tabular}




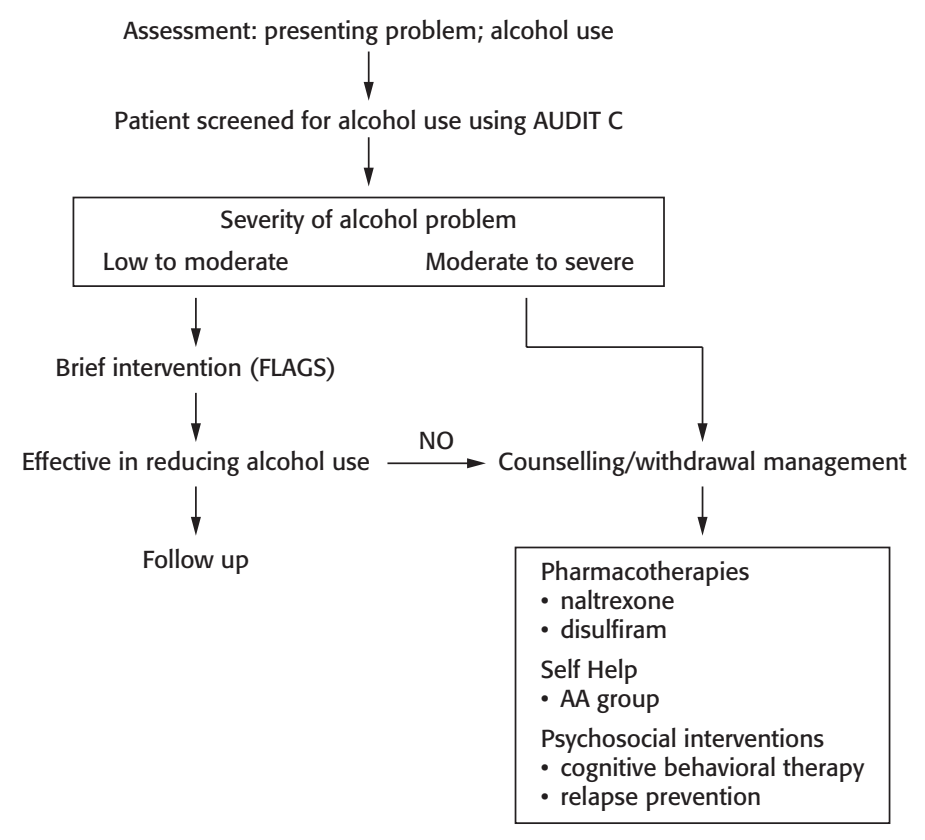

FIGURE 1. Management of problematic drinking

alcohol addiction or abuse problem. The questionnaire is scored from 0 to 12 based on the patient's answers. For men, a score of four or more is considered positive, and for women a score of three and more is considered positive. AUDIT $C$ assesses the frequency and quantity of alcohol use and frequency of heavy drinking (six or more drinks per day) (13). Higher scores indicated more problematic alcohol use.
In case the addiction is not present, but a risk of it appearing is, a short intervention in form of consulting may help the patient reduce the consumption of alcohol. It has been shown that even a short 5-minute intervention reduces drinking (15). Key components of a brief intervention are summarized by the acronym FLAGS (feedback, listening, advice, goals, strategies) (table 3) (12).

TABLE 2. Audit consumption questions

\begin{tabular}{|llllll}
\hline QUESTIONS & $\mathbf{0}$ & $\mathbf{1}$ & $\mathbf{2}$ & $\mathbf{3}$ & $\mathbf{4}$ \\
\hline How often do you have a drink containing alcohol? & never & $\begin{array}{l}\text { Monthly } \\
\text { or less }\end{array}$ & $\begin{array}{l}2-4 \text { times } \\
\text { per month }\end{array}$ & $\begin{array}{l}2-3 \text { times } \\
\text { per week }\end{array}$ & $\begin{array}{l}4+\text { times } \\
\text { per week }\end{array}$ \\
$\begin{array}{l}\text { How many units of alcohol do you drink on a typical } \\
\text { day when you are drinking? }\end{array}$ & $1-2$ & $3-4$ & $5-6$ & $7-9$ & $10+$ \\
$\begin{array}{l}\text { How often have you had } 6 \text { or more units if female } \\
\begin{array}{l}\text { or } 8 \text { or more if male, on a single occasion in the last } \\
\text { year? }\end{array}\end{array}$ & never & $\begin{array}{l}\text { Less than } \\
\text { monthly }\end{array}$ & monthly & weekly & $\begin{array}{l}\text { Daily or } \\
\text { almost daily }\end{array}$ \\
\hline
\end{tabular}

"Adapted from Implementing the ABC alcohol approach in primary care ${ }^{(14)}$

TABLE 3. FLAGS approach

BRIEF INTERVENTION STRUCTURE - FLAGS approach

FEEDBACK about the harms already experienced from alcohol; outline potential health problems that can rise from risky alcohol use such as insomnia, depression, high blood pressure, risk of injury

LISTEN to the patient's response

ADVICE about the importance of changing current drinking patterns. Advice can be supported by self-help materials. Emphasize benefits of reducing drinking (more energy, improved mood, better physical shape)

"Adapted from Implementing the $\mathrm{ABC}$ alcohol approach in primary care ${ }^{(14)}$ 
The key goals for this type of consulting is to give an individual some feedback which is realistic and relevant, listen to the patient and estimate their determination to change, give them clear advice and emphasize the benefits of stopping as well as helping them define their goals and plans on how to achieve them (15). It usually takes several such consultations in order for the patient to change something. This problem can be discussed during the usual patient's visit (it is not recommended to do it each time) and direct confrontations should be avoided. The emphasis should be on helping the patient create and fulfil his own goals. This kind of treatment is not sufficient for true addicts but can be useful when starting the treatment. In their treatment, it is essential to estimate and nourish any sign of abstinence, prevent nutritive deficit and consider including medication which would help preventing relapses. Additionally, it is important to provide the necessary support to family members and other individuals who are involved in the patient's treatment (6). Alcoholism does not threaten only the individual and their family but also the work and other environments (5). Alcoholism leads to the impoverishment of families in both the emotional and material sense (17). A family with an alcoholic is a disturbed community in which there is no collectiveness, cooperation and plans (17). It is important to include all family members in the treatment process as soon as possible to improve family relationships and maintain patient abstinence (8). Family counseling consists of family members and an expert with the function of a counselor. Pharmacotherapy in conjunction with behavioral therapy is another modality to prevent relapse and enhance abstinence. Naltrexone, disulfiram and acamprosate can be prescribed. Naltrexone, an opioid antagonist, reduces the relapse rate by reducing the feeling of reward connected with alcohol consumption as well as the craving for it (18). Although most studies showed a rather poor pharmacotherapeutic effect, persons with certain clinical characteristics such as strong craving for alcohol and family history of alcoholism respond well to naltrexone (19). Acamprosate reduces the craving by reducing the CNS stimulation by affecting GABA and glutamat (20). Disulfiram is the medication that has been used the longest. It discourages the patient for consuming alcohol because the patient expects the appearance of very unpleasant symptoms when even a little alcohol is consumed in combination with it (18). It is recommended for patients who can be monitored. Disulfiram has no effect on craving for alcohol, and the patient must be very motivated to take disulfiram of their own free will (4). Psychological help in form of encouraging motivation and cognitive behavioral therapy is also an important element in alcoholism treatment. In this way, it is possible to maintain their mental and physical health and even improve their social functioning. Additionally, the doctor can encourage the patient to take thiamine to reduce the risk of memory loss and prevent other alcoholism-related complications. The safety of the patient must also be taken into consideration, as well as that of the people in their surroundings, in traffic and at work (professional drivers). In some cases, the doctor is obliged to report the patient to the authorities in order for them to estimate the patient's ability to work and drive. Abstinence syndrome and delirium tremens are serious complications of alcoholism, and pharmacotherapy reaches its full potential if the patient is cared for in the intensive care unit where treatment and surveillance are assured (10). An abstinence crisis is a group of psychical and psychological signs which appear after an alcoholic stops drinking. Mild disorders appear 6 to 7 hours after the drinking stops, and the full clinical picture appears between 24 and 72 hours (21). The dominant disorders are insomnia, fear, anxiety, loss of concentration, irritability and possible hallucinations. Common physical disorders are tremors, fa- 
tigue, nausea, sweating, palpitations and high blood pressure (10). An abstinence crisis without complications is diagnosed if, several hours after the drinking is stopped or the amount is decreased, hand tremors and tongue appear with at least one of the following symptoms: nausea or vomiting, hyperactivity of the vegetative nervous system (tachycardia, sweating), anxiety, depressed mood, short hallucinations, headache and insomnia. Signs of delirium tremens appear after the consummation of large amounts of alcohol is ceased or the amount is significantly decreased (22). The major problem in the treatment of delirium is that it is a multimorbidity condition, partly agitation, anxiety and disalienation (hallucinatory syndrome and convulsive crisis) (23). Detoxification, rehydration and correction of electrolyte imbalance are the first step in adequately carrying out further therapeutic procedures (23). The inability to focus the attention on outside stimulants, incoherent thoughts and at least two of the following symptoms: conscience disorder, perception disorder (hallucinations, illusions), sleep disorder, disorientation in space and time, memory disorder and increased activity of vegetative nervous system. Signs of abstinence syndromes appear when the addict stops or reduces drinking (10). Patients who had mild or moderate abstinence symptoms without epileptic attacks in the anamneses can be treated in the clinic with or without diazepam (24).

\section{CONCLUSION}

Alcoholism, as one of the most common and serious public-health problems which requires long and dedicated treatment, often remains undetected. Development of alcoholism is slow, in average 11 to 13 years. It leads to psychological and physical damage while at the same time causing social, economic and other disorders which influence the whole community. The goal of treatment is to achieve abstinence and realize the rehabilitation and socialization of alcoholics. Family physicians (FP) are in ideal position to detect, prevent and manage the patient's alcohol problems. In most countries, people with alcohol problems will first present to their FP rather than the specialist treatment services (25). FPs have a long-term relationship with their patients, care for several generations of one family and can testify first-hand to the long-term effects of alcohol misuse on the family. Brief interventions are very effective because they can reduce consumption in hazardous drinkers without alcohol dependence (26). Offering counselling and advice on the reduction of alcohol consumption are the key roles in family medicine. FPs have to be educated on skills related to alcohol screening and brief intervention in providing effective service to patients and their families experiencing alcohol-related problems.

\section{REFERENCES}

1. Thaller V, Marušić S. Dijagnostičke I terapijske smjernice za liječenje alkoholom uzrokovanih poremećaja. 2013 Accessible at: http://www.hlz.hr/ smjernice/Smjernice\%20Hrvatskog\%20dru\%C5\%A1 tva\%20za\%20alkoholizma\%20i.pdf .

2. World Health Organization. Global status report on alcohol and health. 2015 Accessible at: http://www.who.int/mediacentre/factsheets/fs349/en/.

3. Gazdek D, Puškaš N. Razvoj programa prevencije poremećaja uzrokovanih prekomjernim pijenjem alkohola u Koprivničko-križevačkoj županiji. HČJZ 2011; 7(28): 1-3.

4. Matošić A, Marušić S, Vidrih B, Kovak-Mufić A, Čičin-Šain L. Neurobiological bases of alcohol addiction. Acta Clin Croat 2016; 55: 134-150.

5. Rapić M, Vrcić-Keglević M. Alkoholizam - zaboravljena dijagnoza u obiteljskoj medicine. Med Fam Croat 2014; 22(2): 25-32.

6. Hotujac Lj. Psihijatrija. Zagreb: Medicinska naklada, 2006.

7. Marušić S, Thaller V. Što je alkoholizam Accessible at: http://www.hskla.hr/ovisnostOalkoholu.htm .

8. Brlek I, Berc G, Milić Babić M. Primjena savjetovanja kao metode pomoći u klubovima liječenih alkoholičara iz perspective socijalnih radnika. Soc.psihijat. 2014; 42(1): 62-70.

9. Miljenović A. Psihosocijalni pristup i alkoholizam: iskustvo rada u klubovima liječenih alkoholičara. Ljetopis socijalnog rada 2010; 17: 281-94. 
10. Warren T. Alcoholism Accessible at: http://emedicine.medscape.com/article/285913-overview\#a0156.

11. Gemini D, lannacone S. Gender and peripheral neuropathy in chronic alcoholism: A clinical-electroneurographic study. Alcohol and Alcoholism 2000; 35: 368-71.

12. Demirkol A, Conigrave K, Haber P. Problem drinking Management in general practice. Australian Family Physician 201 1; 40 (8): $576-82$.

13. Calabria B, Clifford A, Shakeshaft AP et al. Identifying Aboriginal-specific AUDIT-C and AUDIT-3 cutoff scores for at-risk, high-risk, and likely dependent drinkers using measures of agreement with the 10-item Alcohol Use Disorders Identification Test. Addicti Sci Clin Pract $2014 ; 9$ (17): 1-12.

14. Implementing the ABC alcohol approach in primary care. The Royal New Zealand College of General Practitioner, 2012. Accessible at: https:// www.rnzcgp.org.nz/college-resources .

15. Pennay A, Lubman D, Frei M. Alcohol: prevention, policy and primary care responses. Australian Family Physician 2014; 43 (6): 356-361.

16. Haber P, Lintzers N, Proude E, Lapotko O. Guidelines for the treatment of alcohol problems. The Australian Government Department of Health and Aging. 2009. Accessible at: http://www.alcohol.gov.au/internet/alcohol/publishing.nst/Content/864FDC6AD475CB2CCA257693007CDE3A/\$File/treatqui.pdf.

17. Cvančić J, Rozika G. Alkoholizam kao problem u obitelji i društvu. Sestrinski glasnik 2017; 22(1): 23-6.

18. Crowley P. Long-term drug treatment of patients with alcohol dependence. Aust Prescr 2015; 38: 41-3.

19. Bogenschutz MP, Tonigan JS, Pettinati HM. Effects of alcoholism typology on response to naltrexone in the COMBINE study. Alcohol Clin Exp Res 2009; 33(1): 10-18.

20. Davies M. The role of GABA receptors in mediating the effects of alcohol in the central nervous system. J Psychiatry Neurosci 2003; 28 (4): 263-274.

21. Royal College of Physicians. The national clinical guideline center for acute and chronic conditions. Alcohol use disorders: Diagnosis and clinical management of alcohol - related physical comlications. 2010. Accessible at: http://www.ncbi.nlm.nih.gov/pubmedhealth/PMH0047849/pdf/ TOC.pdf.

22. Trevisan LA, Boutros N, Petrakis IL, Krystal JH. Complications of alcohol withdrawal. Pathophysiological insights. Alcohol Health and Research World 1998; 22 (1): 61-6.

23. Novaković M, Đukić Dejanović S, Marić-Burmazević J, Dakić Z, Dimitrijević l. Alcoholic and postoperative delirium: A case-control study. Psychiatria Danubina 2015; 22(1): 90-6.

24. Williams SH. Medications for treating alcohol dependence. American Family Physician 2005; 72 (9): 1775-80.

25. Anderson P. Alcohol and primary health care. WHO regional publications. In: WHO regional publications (ed). European series No. 64. Geneva: World Health Organization; 1996.

26. Forum Clinical Challenge: Alcohol Dependence, 2013 Accessible at: https://www.icgp.ie/assets/46/2646B990-9045-E07D-1E45FFCAEDAEBoCC_document/Clinical_ChallengeOctWEB.pdf. 